\title{
Mezinárodní konference Pulmonary Circulation pořádaná Českou kardiologickou společností pod záštitou European Society of Cardiology a European Respiratory Society
}

V kongresovém centru pražského hotelu Clarion byla ve dnech 2.-5. 6. 2010 uspořádána konference Pulmonary Circulation. Podařilo se nám tak navázat na mnoholetou tradici těchto konferencí, které se pořádaly v Praze od roku 1969 do roku 1999 $\mathrm{v}$ pětiletých intervalech $-\mathrm{v}$ té době byli hlavními organizátory prof. Jiř́i Widimský, prof. Severin Daum, doc. Alois Ouředník a prof. Jan Herget. Tato setkání byla velmi populární a zúčastnili se jich kromě mnoha jiných významných světových kardiologů také prof. Cournand, nositel Nobelovy ceny, a prof. Henri Denolin, prezident European Society of Cardiology (ESC). Od roku 1999 se však tato konference v Praze neuskutečnila, v roce 2006 se podařilo konferenci nově uspořádat polským kolegům, vedeným Adamem Torbickým ve Varšavě - to již bylo pod záštitou ESC a její Working Group on Pulmonary Circulation and Right Ventricular Function. Aktivita členů výboru Pracovní skupiny plicní cirkulace ČKS (prof. Aschermann, MUDr. Jansa, prof. Widimský) pak vedla $\mathrm{k}$ tomu, že pořádání konference po čtyřech letech bylo svěřeno České kardiologické společnosti. Čtyři roky vyčleněné na př́pravu umožnily opakované setkání členů Scientific Committee a bylo to především zásluhou prof. Adama Torbického (Polsko), prof. Jeana-Luca Vachieryho (Belgie), prof. Geralda Simonneaua (Francie), prof. Nazzarena Galieho (Itálie) a českých zástupců (Michaela Aschermanna, Pavla Jansy, Aleše Linharta, Jana Bělohlávka, Jaroslava Lindnera, Jiř́ho Widimského), že se v poslední verzi programu konference objevila většina předních specialistů na problematiku plicní cirkulace z celého světa.

$\mathrm{Na}$ konferenci se z 567 přihlášených účastníků nakonec prezentovalo 476 lékařů z 36 zemí, včetně USA, Argentiny a Mexika. Z Polska se registrovalo téměř 100 lékařů, z České republiky 47 lékařu. Program probíhal 3. 6. a 5. 6. v jednom sále, 4. 6. pak ve dvou paralelních sekcích, celkem bylo předneseno 74 sdělení, převážně pozvanými řečníky. Z 58 zaslaných abstrakt bylo 7 vybráno k ústní prezentaci, 51 pak bylo v sekci posterů, komise vybrala nejlepší tři postery, které byly odměněny zvláštní cenou - učebnicí kardiologie ESC. Je jistě potěšitelné, že účast na přednáškových sekcích byla po celé tř̌i dny velmi dobrá, vždy proběhla kvalitní diskuse, včetně závěrečného Evropského fóra.

První den byly na programu následující bloky přednášek: v zahajovací sekci byla zmíněna historie konferencí plicní cirkulace, Adam Torbicki shrnul období poslední čtyř let od setkání ve Varšavě v roce 2006, Gerald Simonneau měl úvodní přehlednou přednášku s otázkou, kde jsme $\mathrm{v}$ diagnostice a léčbě plicní hypertenze v roce 2010 . V dalších blocích byla věnována pozornost guidelines ESC pro léčbu akutní plicní embolie a plicní hypertenze, dále praktickým postupům v diagnostice a léčbě plicní arteriální hypertenze, non-PAH plicní hypertenze a speciálním situacím u plicní hypertenze (arytmie, hemoptýza, aneurysmata AP, PAH v těhotenství). V další sekci proběhla debata věnovaná off-label používání specifické léčby - jednak u onemocnění levého srdce, jednak u plicních onemocnění, předposlední pak byla sekce o léčbě $\mathrm{PAH}$ a náhlé smrti u $\mathrm{PAH}$. Na závěr prvního dne pak byla přednesena tři vybraná sdělení ze zaslaných abstrakt (M. Luknar, Slovensko, J. Sandoval, Mexiko a J. Krejčí, ČR).

Druhý den pokračoval program paralelně ve dvou sálech. $\mathrm{V}$ sálu A byl celý den věnován problematice plicní embolizace, hluboké žilní trombóze, chronické tromboembolické plicní hypertenzi, v poslední sekci abstrakt zaznělo šest prací věnovaných CTEPH. V sálu B pak byla zařazena nejprve sekce věnovaná problematice $\mathrm{PH}$ v České republice, dále pak velmi dobře obsazená sekce základního výzkumu, screeningu PAH, intervencí u PAH a kongenitálních srdečních vad s PH.

Poslední den zazněla nejprve slavnostní přednáška věnovaná Henrimu Denolinovi - Right ventricle under pressure - přednesl ji Robert Naeije, následovaly dvě vynikající přednášky Norberta Voelkela z USA a Geralda Simonneaua z Francie o dalším výzkumu plicní cirkulace.

Na závěr konference bylo uspořádáno (stejně jako ve Varšavě v roce 2006) tzv. Evropské fórum, na kterém zástupci sedmi evropských zemí představili systémy péče o nemocné s plicní hypertenzí. Můžeme konstatovat, že systém, který jsme za po-

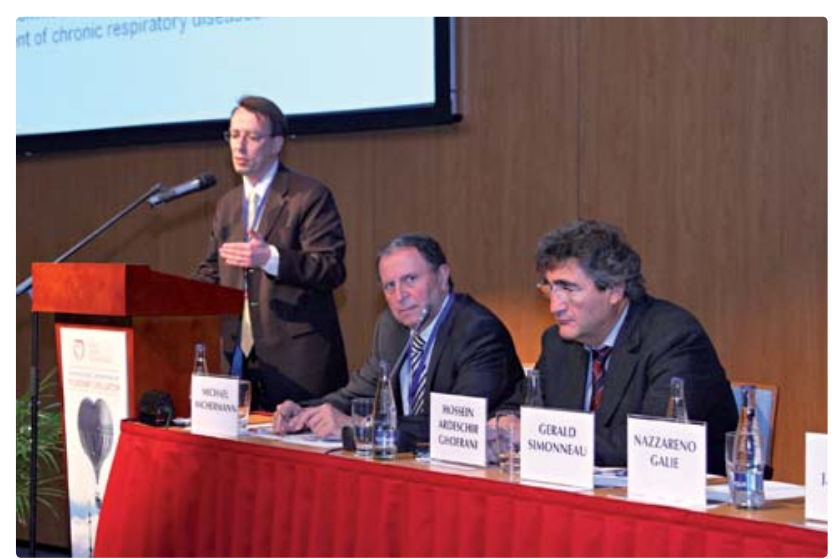

U předsednického pultu M. Humbert, prof. M. Aschermann a prof. G. Simonneau (zleva) 
sledních deset let vytvořili a udržujeme jako funkční v České republice, je předními odborníky ESC považován za velmi kvalitní a hovoři se o něm $s$ velkým uznáním. Hlavními problémy současné péče o nemocné s plicní hypertenzí je jistě včasná diagnostika onemocnění, nedostupnost kauzální léčby a problémy s financováním nákladné léčby.

Součástí programu byla také bohatě navštívená čtyři satelitní symposia společností United Therapeutics, Bayer Schering Pharma, Actelion, GlaxoSmithKline.

Z odborného programu si dovolím ještě vyzdvihnout mimořádně pěkné přednášky českých pozvaných účastníků, v kuloárech na jejich vystoupení zazněla velká chvála a trochu i jisté překvapení nad tím, jak jsme se zařadili mezi evropské známé představitele problematiky plicní cirkulace. Připomenu tedy, že to byli: Aleš Linhart, Debora Karetová, Pavel Jansa, Jan Bělohlávek, Samuel Heller, Jaroslav Lindner (všichni VFN Praha a 1. LF UK), Václav Chaloupecký, Jan Herget (FN Motol a 3. LF UK), Vojtěch Melenovský, Kamil Sedláček (IKEM Praha), Jana Popelová (Nemocnice Na Homolce). Předsedajícími dále byli Michael Aschermann, Jaroslav Lindner, Pavel Jansa, Jan Herget a Václav Chaloupecký, ze Slovenské republiky pak Eva Goncalvesová a Iveta Šimková.

Účastníky konference jsme překvapili mimořádně hezkým společenským večerem, který proběhl ve Španělském sále Pražského hradu. Vystoupení Pavla Šporcla nadchlo všechny přítomné, následující koktajl v Rudolfově galerii a v přilehlých prostorách byl pro všechny krásným zážitkem.

Rád bych na tomto místě poděkoval společnosti Guarant International, která se postarala o kvalitní organizaci konference, dík patří především Ing. Janě Pěkné a Ing. Evě Klimkové. Konferenci by nebylo možné uspořádat bez podpory sponzorů: platinovými sponzory byly společnosti United Therapeutics, Europe Limited a Bayer Health Care, Bayer Schering Pharma, zlatými sponzory pak společnosti Actelion a Lilly, partnerem satelit-

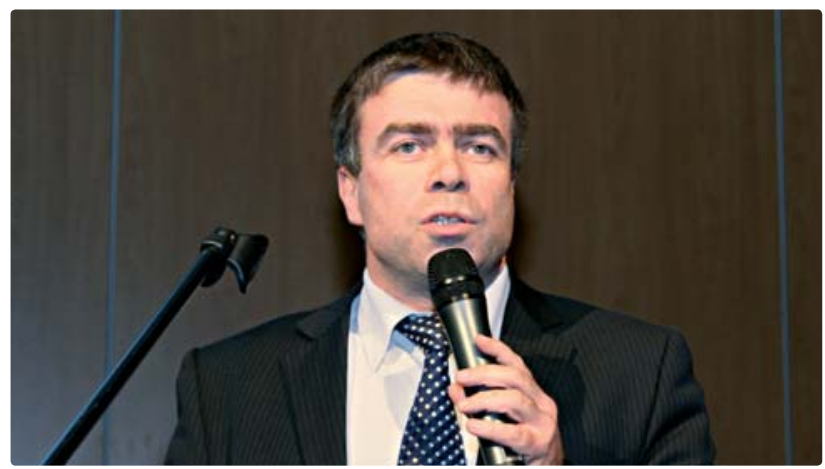

Jedním z přednášejících byl prof. A. Linhart

ního symposia byla společnost GlaxoSmithKline, mediálními partnery byly MEDICAL TRIBUNE CZ a KardioChirurgie.cz, také všem těmto sponzorům a partnerům srdečně děkujeme.

Závěrem je tedy možné konstatovat, že International Conference on Pulmonary Circulation 2010 úspěšně navázala - pod heslem: "Once again in Prague, in the very heart of Europe“ na předchozí symposia česká i symposium polské. Ze strany představitelů Evropské kardiologické společnosti jsme slyšeli jen velkou chválu jak na kvalitu odborného programu, tak na celé uspořádání konference. Můžeme se tedy těšit na další setkání $s$ touto tematikou za čtyři roky. Zatím nebylo rozhodnuto, kde se konference uskuteční, v kuloárech se hovořilo o Budapešti a Bratislavě, rozhodnutí padne zrejemě na kongresu ESC letos ve Stockholmu.

Prof. MUDr. Michael Aschermann, DrSc., FESC, FACC, II. interní klinika kardiologie a angiologie, Všeobecná fakultní nemocnice a 1. lékařská fakulta Univerzity Karlovy, Praha, e-mail:mascher@vfn.cz 